\title{
Aeration Increases Cadmium (Cd) Retention by Enhancing Iron Plaque Formation and Regulating Pectin Synthesis in the Roots of Rice (Oryza sativa) Seedlings
}

\author{
Hubo $\mathrm{Li}^{1+}$, Xiuwen Zheng ${ }^{1 \dagger}$, Longxing Tao ${ }^{2}$, Yongjie Yang ${ }^{2}$, Lei Gao ${ }^{1}$ and Jie Xiong ${ }^{1 *}$ (D)
}

\begin{abstract}
Background: Aeration and water management increasing rhizosphere oxygen amount significantly promote rice (Oryza sativa) growth and yield, but the effect of root aeration on cadmium (Cd) toxicity and accumulation in rice seedlings under hydroponic culture remains unclear.

Results: Results showed that aeration promoted rice seedling growth and alleviated Cd toxicity. Transverse section discovered that $\mathrm{Cd}$ accelerated root mature and senescence while aeration delayed the mature and senescence of roots. Non-invasive Micro-test Technology (NMT) showed that aeration increased net $\mathrm{O}_{2}$ and $\mathrm{Cd}^{2+}$ influxes on the surface of roots while decreased net $\mathrm{Cd}^{2+}$ influx in xylem. Perls blue staining showed that aeration and $\mathrm{Cd}$ treatments increased iron plaque formation on the surface of roots. Results of metal concentration analysis showed that besides increasing $\mathrm{Cd}$ retention in iron plaque, aeration also increasing $\mathrm{Cd}$ retention in the cell wall of rice roots. Cell wall component analysis showed that aeration not only increased pectin content but also decreased pectin methylesterification degree (PMD) by increasing pectin methylesterase (PME) activity.
\end{abstract}

Conclusions: All of these results indicate that aeration not only delays root mature and senescence but also increases $\mathrm{Cd}$ retention in roots by enhancing iron plaque formation and regulating pectin synthesis in the roots of rice seedlings.

Keywords: Aeration, Cadmium, Cell wall, Pectin, Iron plaque, Oxygen, Rice (Oryza sativa)

\section{Background}

Cadmium (Cd) is a toxic heavy metal to rice (Oryza sativa) and mainly ionized as $\mathrm{Cd}^{2+}$ in the rhizosphere (Yoneyama et al. 2015). As a highly mobile and soluble metal, Cd exposure reduces crops yield and does harm to humans' health even at low concentrations. Rice is a staple food consumed by half the world's population, especially in East and South Asia, the Middle East, Latin America, and the West Indies (Sharif et al. 2014). Due to daily consumption, $\mathrm{Cd}$ in rice grains poses a latent health problem to humans through food chains and leads to chronic toxicity. The outbreak of "Itai-itai disease" in the mid-twentieth century in Japan is due to consumption of Cd-contaminated rice

\footnotetext{
* Correspondence: jiexiong@zju.edu.cn

†Hubo Li and Xiuwen Zheng contributed equally to this work.

'School of Life Sciences and Medicine, Zhejiang Sci-Tech University,

Hangzhou 310018, People's Republic of China

Full list of author information is available at the end of the article
}

(Horiguchi et al. 1994). Even in recent years, Cd exposure in general Japanese population can be as high as $3-4 \mathrm{mg}$ $\mathrm{kg}^{-1}$ body weights every week (Tsukahara et al. 2003). Furthermore, as an export commodity, rice also has posed an increasing threat to human health globally due to the contamination by $\mathrm{Cd}$. Therefore, it is necessary to reduce the concentration of rice $\mathrm{Cd}$ below the allowable level indicated by the Codex Alimentarius Commission of FAO/ WHO (CODEX 2006).

In response to $\mathrm{Cd}$ toxicity, plants have evolved several protective mechanisms against $\mathrm{Cd}$ toxicity, including avoidance and tolerance strategies (Dalcorso et al. 2010). Plants can prevent $\mathrm{Cd}$ from entering into plant cells, which is referred to as an avoidance strategy. To provide a barrier for metals toxic, formation of iron plaque on root surface has been considered as a crucial survival strategy for wetland plants, such as rice, in anoxic and flooded environments 
(Smolders and Roelofs 1996; Chabbi 1999). The formation of iron plaque on the root surface due to the radial oxygen loss (ROL) and oxidants in the rhizosphere, where ferrous is subsequently oxidized to ferric iron with the precipitation of iron oxide or hydroxide on the root surface (Chen et al. 1980; Taylor et al. 1984). Root iron plaque has been shown to impede the entry of metal ions, such as $\mathrm{Cd}, \mathrm{Al}, \mathrm{Pb}$ and $\mathrm{Zn}$ in plants (Chen et al. 2006; Liu et al. 2007; Deng et al. 2009). On the other hand, plant cell wall is another barrier to prevent $\mathrm{Cd}$ from entering and damaging the protoplast. Both the primary and secondary cell wall have an array of defensive mechanisms that can be adapted to cope with $\mathrm{Cd}$ (Lux et al. 2011). The main components of plant cell walls are cellulose, hemicellulose, pectin, and glycoprotein. More than 25 years ago, Poschenrieder et al. (1989) presumed that $\mathrm{Cd}$ increases the cross linking of pectin in the middle lamella and inhibits cell expansion growth. Now it has been well established that negatively charged pectin strongly binds positively charged cations to form a stable gel with each other in cell walls (Kohn 1987; Liners et al. 1989), and there is a close positive correlation between pectin content and heavy metal accumulation in cell walls (Schmohl and Horst 2000; Paynel et al. 2009; Xiong et al. 2009b). It is now well suggested that pectin is polymerized in the cis Golgi, methylesterified in the medial Golgi and substituted with side chains in the trans Golgi cisternae (Micheli 2001). Pectin is secreted in a highly methylesterified form and demethylesterified by pectin methylesterase (PME), pectin methylesterification degree (PMD) determines negative charges and has a close negative correlation with heavy metal adsorption in the cell walls of plant roots (Eticha et al. 2005; Yang et al. 2008). Ishikawa et al. (2011) suggested Cd uptake could be mediated by transporters. In fact, $\mathrm{Cd}$ entrance into root cells via transporter OsNRAMP5 or OsIRT1 have been proved and OsNRAMP5 is predominantly applied (Nakanishi et al. 2006; Sasaki et al. 2012). In addition, higher expression of OsNRAMP1 in root could enhance Cd accumulation in shoot of rice, indicating that OsNRAMP1 was also related with Cd uptake and transport (Takahashi et al. 2011). The abilities of resistance to $\mathrm{Cd}$ stress inside the cells are referred to as tolerance strategy (Choppala et al. 2014). In rice, phytochelatins $(\mathrm{PC})$ acting as Cd chelator plays a key role in Cd detoxification (Yadav et al. 2010). PC chelates $\mathrm{Cd}$ in the cytosol and forms complexes with $\mathrm{Cd}$. Then the $\mathrm{Cd}-\mathrm{PCs}$ complexes are sequestered in the vacuoles via specific transporters located at tonoplast (Ueno et al. 2010; Miyadate et al. 2011).

Several approaches have been proposed to reduce $\mathrm{Cd}$ concentration in rice culture, such as soil dressing, chemical remediation, and breeding or engineering low-Cd-accumulating cultivars (Ishikawa et al. 2006; Uraguchi et al. 2006; Makino et al. 2008; Ueno et al. 2011). As a commonly used type of water management, flooding treatment often leads to a reduction in oxygen or even oxygen deficiency due to the slower diffusion of gases in water than in air and exacerbated by the competition for oxygen consumption by soil microorganisms (Bailey-Serres and Voesenek 2008). Numerous studies have revealed that root uptake of ions and transport of ions to shoots is severely inhibited under waterlogging (anoxia) conditions (Pang et al. 2004; Smethurst et al. 2005). It is reported that $\mathrm{Cd}$ is mainly present as free $\mathrm{Cd}^{2+}$ in soil under aerobic condition regardless of soil redox potential (Du Laing et al. 2009). It was suggested that $\mathrm{Cd}$ in soil existed in insoluble form as sulfide in the flooding period, flooding during the growing season, especially during later stages of plant growth, can effectively reduce $\mathrm{Cd}$ concentrations in rice grains. So continuous flooding treatment is considered to be a simple method to inhibit $\mathrm{Cd}$ absorption in rice culture by reducing oxygen and free $\mathrm{Cd}^{2+}$ concentration (Daum et al. 2001; Cattani et al. 2008). Hu et al. (2013a, 2013b) reported that the $\mathrm{HCl}$-extractable $\mathrm{Cd}$ concentrations decreased significantly with increasing irrigation from aerobic to flooded conditions. In contrast, Yang et al. (2009) reported that compared to the well-watered treatment, moderate soil drying (MD, re-watered when soil water potential decreased to $-20 \mathrm{kPa}$ ) and severe soil drying (SD, re-watered when soil water potential decreased to $-40 \mathrm{kPa}$ ) increased $\mathrm{Cd}$ content in roots while they reduced it in the straw. MD reduced $\mathrm{Cd}$ content by $19-21 \%$ in the grain and by $40 \%$ in milled rice. The SD significantly increased $\mathrm{Cd}$ content in the grain but reduced it in milled rice (Yang et al. 2009). Furthermore, Yang et al. (2017) also reported that moderate wetting and drying increases rice yield and reduce water use, grain arsenic level and methane emission.

However, soil drying treatment is quite different from root aeration treatment. Although soil drying can increase rhizosphere oxygen amount, it also can seriously affect rice growth and development. Oxygen is positive for the growth of rice, root aeration and other methods to increase the rhizosphere oxygen amount significantly promoted rice growth and yield in the paddy field (Zhu et al. 2015; Yang et al. 2017). But to date, the effect and mechanism of root aeration on $\mathrm{Cd}$ accumulation in rice seedlings remains unclear. In this study, in order to investigate the effect of root aeration on $\mathrm{Cd}$ accumulation in rice seedlings, hydroponic culture was used to avoid interferes of different forms of $\mathrm{Cd}$ caused by soil redox potential and $\mathrm{pH}$ value in soil.

\section{Methods}

Rice Hydroponic Culture, $\mathrm{Cd}$ and Aeration Treatment

Healthy rice (O. sativa L., cv. Nipponbare) seeds were surface sterilized using 5\% sodium hypochlorite for $15 \mathrm{~min}$, and the seeds were then washed 3 times with sterilized water. After soaking in sterilized water at $37^{\circ} \mathrm{C}$ for $48 \mathrm{~h}$, the seeds were germinated in Petri dishes with wet filter paper at $37^{\circ} \mathrm{C}$ for another $24 \mathrm{~h}$. Germinated seeds were 
then transferred to a net tray floating on a container filled with sterilized water ( $\mathrm{pH}$ 5.2) for 1 week. Then, sterilized water was replaced with improved Yoshida rice nutrient solution in full strength (Yoshida et al. 1976) for another 2 weeks. The Yoshida rice nutrient solution contains the following components (in $\mathrm{mM}$ ): $\mathrm{NH}_{4} \mathrm{NO}_{3}, 1.43 ; \mathrm{CaCl}_{2}, 1.00$; $\mathrm{MgSO}_{4}, 1.64 ; \mathrm{K}_{2} \mathrm{SO}_{4}, 1.00 ; \mathrm{NaH}_{2} \mathrm{PO}_{4}, 0.32 ; \mathrm{FeCl}_{3}, 3.6 \times 10^{-}$ ${ }^{2} ; \mathrm{MnCl}_{2}, 9.4 \times 10^{-3} ; \mathrm{H}_{3} \mathrm{BO}_{3}, 1.9 \times 10^{-2} ;\left(\mathrm{NH}_{4}\right)_{6} \mathrm{Mo}_{7} \mathrm{O}_{24}$, $5.17 \times 10^{-4} ; \mathrm{ZnSO}_{4}, 1.52 \times 10^{-4} ; \mathrm{CuSO}_{4}, 1.36 \times 10^{-4}$ and $\mathrm{Na}_{2} \mathrm{SiO}_{3}, 5.00 \times 10^{-3} . \mathrm{FeCl}_{3}$ was replaced with $3.1 \times 10^{-2}$ $\mathrm{mM} \mathrm{Fe}{ }^{2+}$-EDTA as source of Fe. Finally, 3-week-old uniform seedlings were transplanted into 5 -L black plastic pot containing full strength Yoshida rice nutrient solution (4 seedlings per pot), with either no $\mathrm{Cd}$ (control) or $50 \mu \mathrm{M} \mathrm{Cd}$ $\left(\mathrm{CdCl}_{2}\right)$. Half the rice seedlings were aerated using an air pump (30 min per hour, $\mathrm{O}_{2}$ concentration in nutrient solution was around $7.0 \pm 0.5 \mathrm{mg} / \mathrm{L}$ ), while the other half were continuously treated as previously described. Totally, there were 4 treatments: control, aeration, $50 \mu \mathrm{M} \mathrm{Cd}$ and aeration plus $50 \mu \mathrm{M} \mathrm{Cd}$. Each treatment was set up in triplicate to ensure the reproducibility of the results. The $\mathrm{pH}$ of the nutrient solution was adjusted to 5.2 with $\mathrm{NaOH}$ or $\mathrm{HCl}$ every $3 \mathrm{~d}$, and the nutrient solution was refreshed every $6 \mathrm{~d}$. All seedlings were grown in a plant growth chamber with $14 \mathrm{~h}$ at $30^{\circ} \mathrm{C}: 10 \mathrm{~h}$ at $24{ }^{\circ} \mathrm{C}$ day: night photoand thermoperiod, and $80 \%$ relative humidity.

\section{Growth Analysis}

Root length and shoot height were measured with an accuracy of $\pm 1 \mathrm{~mm}$ with the help of a ruler. For biomass determination, the shoot and root of seedlings were separated and dried at $105^{\circ} \mathrm{C}$ for $1 \mathrm{~h}$ and then dried at $80^{\circ} \mathrm{C}$ for another $48 \mathrm{~h}$. After cooling, the dry weight of shoot and root were weighed and recorded. For root diameter determination, roots were hand sectioned and transverse sections were taken from $0.5 \mathrm{~cm}$ to $1 \mathrm{~cm}$ behind the root apex; the root diameter was then measured and analyzed by microscope and software (DM4000B, Leica, Wetzlar, Germany). At least 5 repeats were measured for each treatment.

\section{Determination of $\mathrm{Net} \mathrm{Cd}^{2+}$ and $\mathrm{O}_{2}$ Fluxes}

Net $\mathrm{O}_{2}$ and $\mathrm{Cd}^{2+}$ flux were measured in YoungerUSA Xuyue (Beijing) BioFunction Institute by using Non-invasive Micro-test Technology (NMT) (NMT100 Series, YoungerUSA LLC, Amherst, MA, USA; Xuyue (Beijing) Sci. \& Tech. Co., Ltd., Beijing, China and imFluxes V2.0 (YoungerUSA LLC, Amherst, MA, USA) Software, which is capable of integrating and coordinating differential voltage signal collections, motion control, and image capture simultaneously. For net $\mathrm{Cd}^{2+}$ flux determination, a 1-cm length of filling liquid $\left(10 \mathrm{mM} \mathrm{Cd}\left(\mathrm{NO}_{3}\right)_{2}, 0.1 \mathrm{mM} \mathrm{KCl}\right)$ was injected into a pre-pulled and salinized glass microsensor $(\Phi 4.5 \pm$ $0.5 \mu \mathrm{m}$, XY-CGQ-01, YoungerUSA), and then the glass microsensor was front filled with $40-50 \mu \mathrm{m}$ column of $\mathrm{Cd}^{2+}$ liquid exchange reagent (LIX, YoungerUSA). Finally, an Ag/ $\mathrm{AgCl}$ wire microsensor holder YG003-Y11, (YoungerUSA) was inserted in the back of the microsensor to make electrical contact with the electrolyte solution. In net $\mathrm{Cd}^{2+}$ flux measurement, standard solutions containing $10 \mu \mathrm{M}$ or $100 \mu \mathrm{M} \mathrm{CdCl}_{2}$ as well as $0.1 \mathrm{mM} \mathrm{KCl}, 0.1 \mathrm{mM} \mathrm{CaCl} 2$ and $0.3 \mathrm{mM}$ MES at $\mathrm{pH} 5.4$ were used to calibrate the microelectrode. Calibration was achieved when the Nernst slope drawn through two points was $29 \pm 3 \mathrm{mV} /$ decade. After 2 week treatments, $3 \mathrm{~cm}$ length roots from the root apex were cut and rinsed in distilled water, and then transferred to a plastic Petri dish containing a test solution of $10 \mu \mathrm{M} \mathrm{CdCl}_{2}$ at $\mathrm{pH}$ 5.4. After $10 \mathrm{~min}$ of equilibration, tests were carried out on root micro-zones with a step pitch of $30 \mu \mathrm{m}$. In net $\mathrm{O}_{2}$ flux measurement, The $\mathrm{Pt} / \mathrm{Ir}$ polarographic oxygen microsensor ( $\$ 20 \pm 5 \mu \mathrm{m}$, XY-CGQ-501, YoungerUSA) were used for detecting dissolved oxygen in $-750 \mathrm{mV}$ polarization voltage. The oxygen microsensor was calibrated with nitrogen-saturated and control cultural solution. The different root zones were distinguished by their morphological properties as observed under a microscope. Measurements made on the root surface 200 and $500 \mu \mathrm{m}$ from the root apex represented the meristematic zone and the growth zone respectively. Transverse section at $500 \mu \mathrm{m}$ from the root apex were taken to measure fluxes in xylem. Steady-state $\mathrm{Cd}^{2+}$ and $\mathrm{O}_{2}$ flux were recorded for $10 \mathrm{~min}$, and each measurement was repeated three times. The micro-volt differences were then exported as raw data before they were imported and converted into net fluxes by using the JCal V3.3 (a free MS Excel spreadsheet, youngerusa.com or xbi.org).

\section{Analysis of Iron Plaque}

Perls blue staining of iron plaque was performed according to the method of Yokosho et al. (2009). Briefly, equal amounts of solutions of $4 \%(v / v) \mathrm{HCl}$ and $4 \%(w / v)$ potassium ferrocyanide were mixed immediately prior to use. Roots of rice seedlings (3-week-old) were exposed to the staining solution and vacuum infiltrated for 15 min. The staining was observed under stereomicroscope.

Iron plaque was extracted from fresh root surface using the dithionite-citrate-bicarbonate method (DCB) (Taylor and Crowder 1983). Fresh root material was placed in a solution of $40 \mathrm{ml}$ of $0.3 \mathrm{M}$ sodium citrate $\left(\mathrm{Na}_{3} \mathrm{C}_{6} \mathrm{H}_{5} \mathrm{O}_{7} \cdot 2 \mathrm{H}_{2} \mathrm{O}\right)$ and $5 \mathrm{ml}$ of $1.0 \mathrm{M}$ sodium bicarbonate $\left(\mathrm{NaHCO}_{3}\right)$ at $25^{\circ} \mathrm{C}$. Three grams of sodium dithionite $\left(\mathrm{Na}_{2} \mathrm{~S}_{2} \mathrm{O}_{4}\right)$ was added and the mixture was agitated continuously for $3 \mathrm{~h}$. After the 3-h extraction period, the wash was collected and the roots were washed three times with $15 \mathrm{ml}$ of deionized water. The resulting solution was made to volume $(100 \mathrm{ml})$ with deionized water. $\mathrm{Cd}$ and $\mathrm{Fe}$ content in the resulting solution were then measured using an atomic absorption spectrometer (AA-6800, Shimadzu, Kyoto, Japan). 


\section{Analysis of $\mathrm{Cd}$ and Fe Content in Rice Tissue}

After the DCB extraction, seedlings were dissected into root and shoot. Half the root was used to analyze distribution of $\mathrm{Cd}$ in root cells according to the method of Carrier et al. (2003) with tiny modifications. Each $5 \mathrm{~g}$ sample was homogenized in $10 \mathrm{ml}$ of chilled extraction buffer containing 50 $\mathrm{mM}$ Hepes (pH 7.5), $500 \mathrm{mM}$ sucrose, $1 \mathrm{mM}$ DTT, $5 \mathrm{mM}$ ascorbate and $1 \%$ polyvinylpolypyrrolidone (PVPP). The homogenate was centrifuged at $500 \mathrm{~g}$ for $5 \mathrm{~min}$ to isolate the cell wall fraction. Then the supernatant was centrifuged at $20,000 \mathrm{~g}$ for $45 \mathrm{~min}$ to sediment cell organelles, the resultant supernatant solution was referred to as the soluble fraction. All steps were performed at $4{ }^{\circ} \mathrm{C}$. The fractions of the samples were digested in a mixture of $\mathrm{HNO}_{3}$ and $\mathrm{HClO}_{4}(4: 1, v /$ v) at $120^{\circ} \mathrm{C}$ for at least $3 \mathrm{~h}$. Another half of root and shoot were dried at $105^{\circ} \mathrm{C}$ for $1 \mathrm{~h}$ and then were dried for another $48 \mathrm{~h}$; the dry samples were digested in mixture of 4:1 $(\mathrm{v} / \mathrm{v})$ $\mathrm{HNO}_{3}$ and $\mathrm{HClO}_{4}$ at $120^{\circ} \mathrm{C}$ for at least $3 \mathrm{~h}$. Cd and Fe content also were quantified using an atomic absorption spectrometer (AA-6800, Shimadzu, Kyoto, Japan).

\section{Cell Wall Fractionation and Measurement}

Based on the methods of Zhong and Läuchli (1993), the crude cell walls were prepared and fractionated into four fractions: pectin, hemicellulose1 (HC1), hemicellulose 2 ( $\mathrm{HC} 2)$, and cellulose. Uronic acid content in pectin, $\mathrm{HC} 1$ and $\mathrm{HC} 2$ was assayed according to the method of Blumenkrantz and Asboe-Hansen (1973). Galacturonic acid (GalA) was used as a calibration standard and pectin content was expressed as GalA equivalents. Cellulose content was assayed according to the methods of Correa-Aragunde et al. (2008).

\section{PME Activity Assay}

PME was extracted according to the method of Ren and Kermode (2000) with modification; fresh roots were fully ground in the PME extraction buffer $(0.1 \mathrm{M}$ citrate acid, $0.2 \mathrm{M} \mathrm{Na}_{2} \mathrm{HPO}_{4}$, and $1.0 \mathrm{M} \mathrm{NaCl}, \mathrm{pH} 5.0$ ) at $4{ }^{\circ} \mathrm{C}$. The homogenized slurry was transferred to an Eppendorf tube and incubated on ice for $1 \mathrm{~h}$, during which it was vibrated 3 times at $20 \mathrm{~min}$ intervals, and then the tube was centrifuged for $10 \mathrm{~min}$ at $15,000 \mathrm{~g}$ at $4{ }^{\circ} \mathrm{C}$. The supernatant was collected for PME activity determination. PME activity was determined according to the method of Richard et al. (1994). The extract was added to the PME activity assay buffer $(0.5 \%(w / v)$ citrus pectin, $0.2 \mathrm{M} \mathrm{NaCl}$, and $0.15 \%(w / v)$ methyl red ( $\mathrm{pH} 6.8)$, then the mixture was incubated for $1.5 \mathrm{~h}$ at $37^{\circ} \mathrm{C}$. Pectin de-esterification decreases the $\mathrm{pH}$, thus changing the color from yellow to red. The color change was recorded at $525 \mathrm{~nm}$ with a spectrophotometer. A calibration curve was obtained by adding $10-300 \mu \mathrm{l} 0.01 \mathrm{M} \mathrm{HCl}$ to $4 \mathrm{ml}$ PME activity assay buffer and the respective optical density (OD) values were measured at $525 \mathrm{~nm}$.
Determination of Degree of Pectin Methylesterification

The degree of pectin methylesterification was calculated from the ratio of the methanol and GalA content according to the method of Anthon and Barrett (2008). Methanol was determined using $\mathrm{AO}$ and Purpald as described in the method of Anthon and Barrett (Anthon and Barrett 2004), and GalA content was assayed according to the method of Blumenkrantz and Asboe-Hansen (1973).

\section{Statistical Analysis}

The data were analyzed by analysis of variance (ANOVA). ANOVA and the difference (least-significant difference, LSD) test were employed to determine differences among the treatments at $P<0.05$.

\section{Results}

\section{Effects of $\mathrm{Cd}$ and Aeration on Rice Growth and Root} Structure

Compared with control, Cd treatment not only inhibited shoot height and root length but also reduced biomass accumulation (dry weight of shoot and root) of rice seedlings (Fig. 1). In the absence of $\mathrm{Cd}$, aeration showed an obvious growth-promoting effect on rice seedlings, statistical results showed that aeration significantly increased shoot height, root length and dry weight. In the presence of $\mathrm{Cd}$, aeration alleviated $\mathrm{Cd}$-caused inhibitions on shoot height and root length, although it had not significant effect on dry weight of rice seedlings (Fig. 1). Totally, aeration slightly alleviated $\mathrm{Cd}$ toxicity to rice seedlings.

Results of transverse section showed that aeration increased the diameter of root by increasing cell size rather than cell layer (Fig. 2a). In addition, transverse section of root at $1 \mathrm{~cm}$ from root apex showed that aeration slightly inhibited aerenchyma development (Fig. 2b). In the control, many lacunae extended radially from the endodermis to the outer cortex were separated by narrow sections of parenchyma cells, while aerated root showed more parenchyma cells with less aerenchyma (Fig. $2 \mathrm{~b}$ ). In the presence of $\mathrm{Cd}$, transverse section of root at $1 \mathrm{~cm}$ from root apex showed that $\mathrm{Cd}$ treatment obviously promoted aerenchyma development, lacunae extended radially from the endodermis to the outer cortex with limited parenchyma cells. Aeration alleviated $\mathrm{Cd}$-induced aerenchyma formation and increased parenchyma cells.

\section{Effects of $\mathrm{Cd}$ and Aeration on net $\mathrm{O}_{2}$ and $\mathrm{Cd}^{2+}$ Fluxes in Rice Root}

Effects of $\mathrm{Cd}$ and aeration on net $\mathrm{O}_{2}$ and $\mathrm{Cd}^{2+}$ fluxes in rice root were investigated using NMT, a positive net flux represented efflux and a negative net flux represented influx. The results showed that obvious net $\mathrm{O}_{2}$ fluxes were detected in elongation and meristematic zones rather than xylem (Fig. 3). In contrast, intensive net $\mathrm{Cd}^{2+}$ flux was detected in xylem, less net $\mathrm{Cd}^{2+}$ flux was detected in 


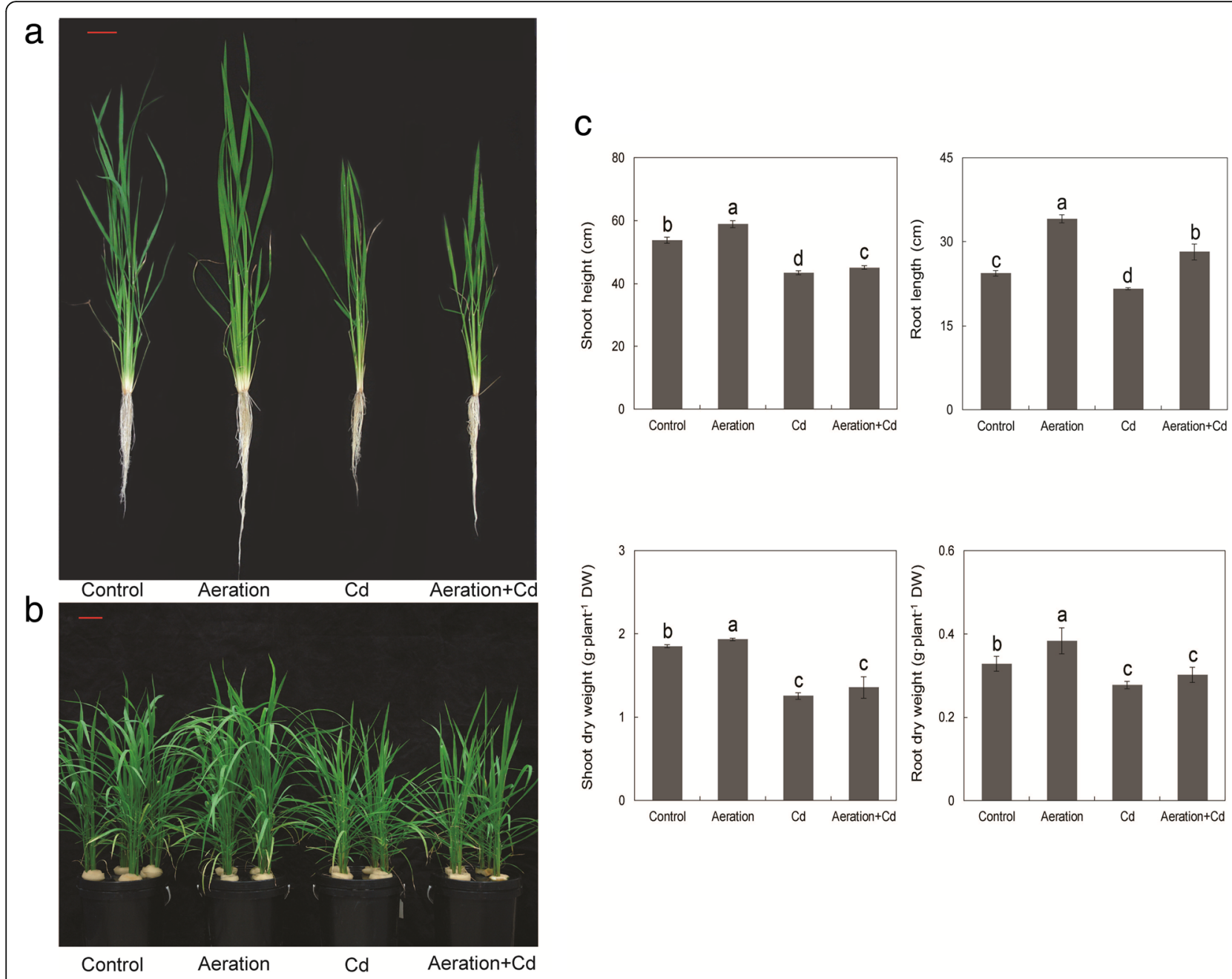

Fig. 1 Effects of aeration or/and $50 \mu \mathrm{M} \mathrm{CdCl}_{2}$ treatments on the growth of rice seedling. a Intact seedling growth phenotype, bar indicates $5 \mathrm{~cm}$; b Hydroponic culture condition, bar indicates $5 \mathrm{~cm}$; c Shoot height, root length, shoot dry weight and root dry weight of rice seedlings. The $3-$ week-old rice seedlings under hydroponic culture were aerated with air pump (30 min per hour) in the absence or presence of $50 \mu \mathrm{M} \mathrm{CdCl}$ for $14 \mathrm{~d}$. The values are means $\pm \mathrm{SE}(n=8)$. Different letters on bar indicate significant differences at $P<0.05$

meristematic zone and the least net $\mathrm{Cd}^{2+}$ flux was detected in elongation zone. In addition, net $\mathrm{Cd}^{2+}$ flux in meristematic zone decreased gradually as the duration. Aeration obviously increased net $\mathrm{O}_{2}$ fluxes in elongation and meristematic zones of rice root with or without $\mathrm{Cd}$ stress. $\mathrm{Cd}$ treatment increased net $\mathrm{O}_{2}$ fluxes in elongation and meristematic zones of rice root at the first several minutes, and then increased net $\mathrm{O}_{2}$ fluxes recovered to the control level gradually. As to net $\mathrm{Cd}^{2+}$ flux, aeration obviously increased net $\mathrm{Cd}^{2+}$ flux in elongation zone while decreased net $\mathrm{Cd}^{2+}$ flux in xylem. Aeration also slightly increased net $\mathrm{Cd}^{2+}$ flux in meristematic zone, although net $\mathrm{Cd}^{2+}$ flux decreased gradually as the duration.

\section{Effects of $\mathrm{Cd}$ and Aeration Treatments on Iron Plaque}

Results of Perls blue staining showed that aeration significantly increase blue color on the surface of root tip in the absence of $\mathrm{Cd}$ stress. Meanwhile, $\mathrm{Cd}$ treatment also slightly increased blue color on the surface of root tip, Cd plus aeration treatment increased the most obvious blue color on the surface of root tip (Fig. 4a). Metal content analysis showed that aeration significantly increased Fe content in iron plaque of rice roots, regardless of whether it was exposed to Cd treatment or not (Fig. 4b). Furthermore, Cd treatment also had a certain effect on promoting iron plaque formation (Fig. 4b). In addition, $\mathrm{Cd}$ also was detected in the iron plaque and aeration increased $\mathrm{Cd}$ content in the iron plaque of rice roots under $\mathrm{Cd}$ treatment (Fig. 4c).

\section{Effects of $\mathrm{Cd}$ and Aeration Treatments on $\mathrm{Cd}$ and Fe Contents in Rice Seedlings}

The results showed that $50 \mu \mathrm{M} \mathrm{CdCl}_{2}$ treatment significantly increased $\mathrm{Cd}$ content in both shoots and roots 
a

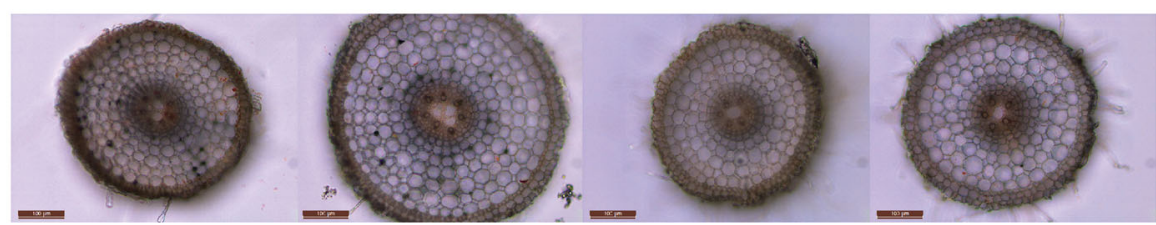

Control Aeration

Cd

Aeration $+\mathrm{Cd}$

b
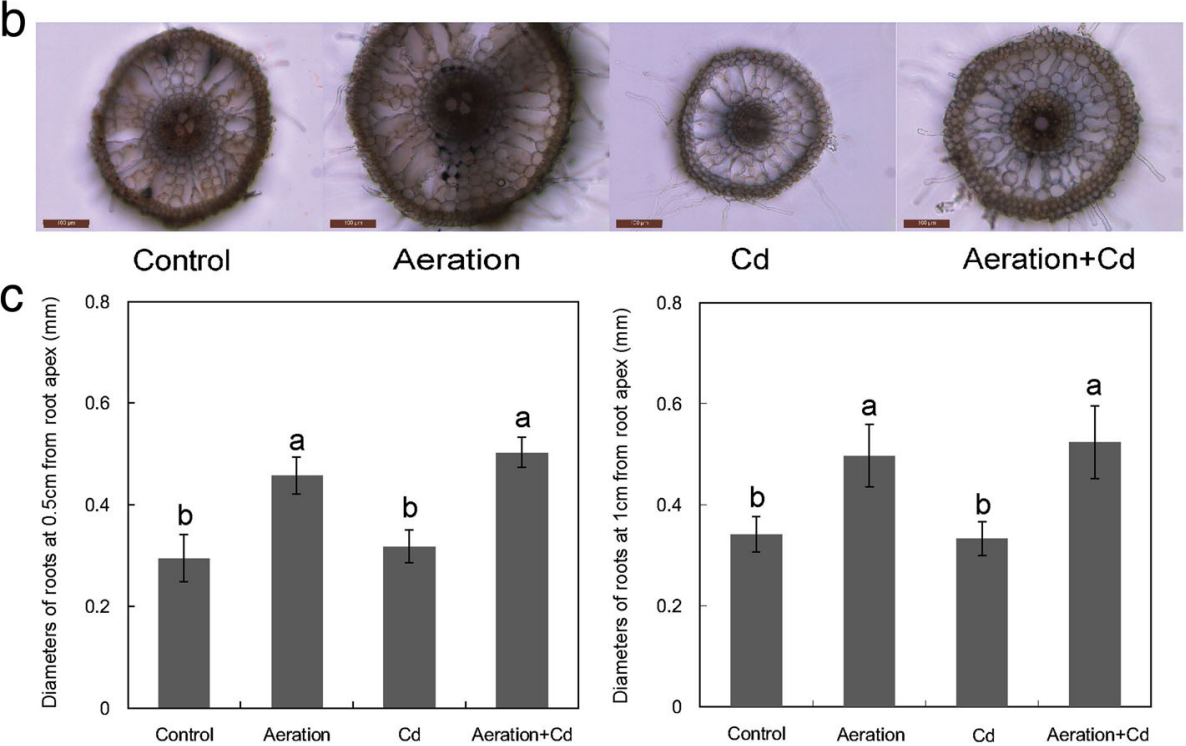

Fig. 2 Effects of aeration or/and $50 \mu \mathrm{M} \mathrm{CdCl} 2$ treatments on the structure of rice root. a Transverse section at $0.5 \mathrm{~cm}$ from root apex, bar indicates $100 \mu \mathrm{m}$; b Transverse sections of root at $1 \mathrm{~cm}$ from root apex, bar indicates $100 \mu \mathrm{m}$; c Diameters of roots at $0.5 \mathrm{~cm}$ and $1 \mathrm{~cm}$ from root apex. The 3-week-old rice seedlings under hydroponic culture were aerated with air pump (30 min per hour) in the absence or presence of 50 $\mu \mathrm{M} \mathrm{CdCl} 2$ for $14 \mathrm{~d}$. The values are means $\pm \mathrm{SE}(n=5)$. Different letters on bar indicate significant differences at $P<0.05$

(after the DCB extraction of iron plaque) of rice seedlings (Fig. 5a, b). However, aeration increased Cd content in roots (after the DCB extraction of iron plaque) but decreased $\mathrm{Cd}$ content in shoots. As to Fe content in rice seedlings without $\mathrm{Cd}$ treatment (Fig. 5c, d), aeration increased Fe content in roots but had no obvious effect on Fe content in shoots. Meanwhile, Cd treatment decreased Fe contents in both shoots and roots (after the DCB extraction of iron plaque) of rice seedlings, aeration increased Fe content in roots (after the DCB extraction of iron plaque) but had no obvious effect on Fe content in shoots.

Distribution analysis of $\mathrm{Cd}$ in rice root cells (after the DCB extraction of iron plaque) showed most of $\mathrm{Cd}$ accumulated in cell walls and the least amount of $\mathrm{Cd}$ in cell organelles. Aeration increased $\mathrm{Cd}$ content in cell walls but decreased $\mathrm{Cd}$ contents in cell organelles and soluble fractions (Fig. 6).

\section{Effects of $\mathrm{Cd}$ and Aeration Treatments on Cell Wall Components in Rice Roots}

Cell wall components were divided into pectin, $\mathrm{HC} 1, \mathrm{HC} 2$ and cellulose with graduation extraction method. Compared with control, aeration treatment increased pectin content but decreased cellulose content in the cell wall of rice roots (Fig. 7). Cd treatment increased pectin, $\mathrm{HC} 1$ and $\mathrm{HC} 2$ contents but decreased cellulose content. Cd plus aeration treatment induced the most obvious increases of pectin, $\mathrm{HC} 1$ and $\mathrm{HC} 2$ contents in the cell wall of rice roots, although it decreased cell wall cellulose content obviously.

\section{Effects of $\mathrm{Cd}$ and Aeration Treatments on Pectin Methylesterification and PME Activity}

Compared with control, $\mathrm{Cd}$ treatment decreased pectin methylesterification degree and increased PME activity in the cell wall of rice roots (Fig. 8). Aeration treatment also decreased pectin methylesterification degree and increased PME activity in the cell wall of rice roots. Cd plus aeration treatment has the most intensive effects on decreasing pectin methylesterification degree and increasing PME activity in the cell wall of rice roots.

\section{Discussion}

Aeration Delays Cd-accelerated Mature and Senescence of Rice Roots

In the absence of $\mathrm{Cd}$, aeration significantly increased root length (Fig. 1), indirectly proves aeration delays root 


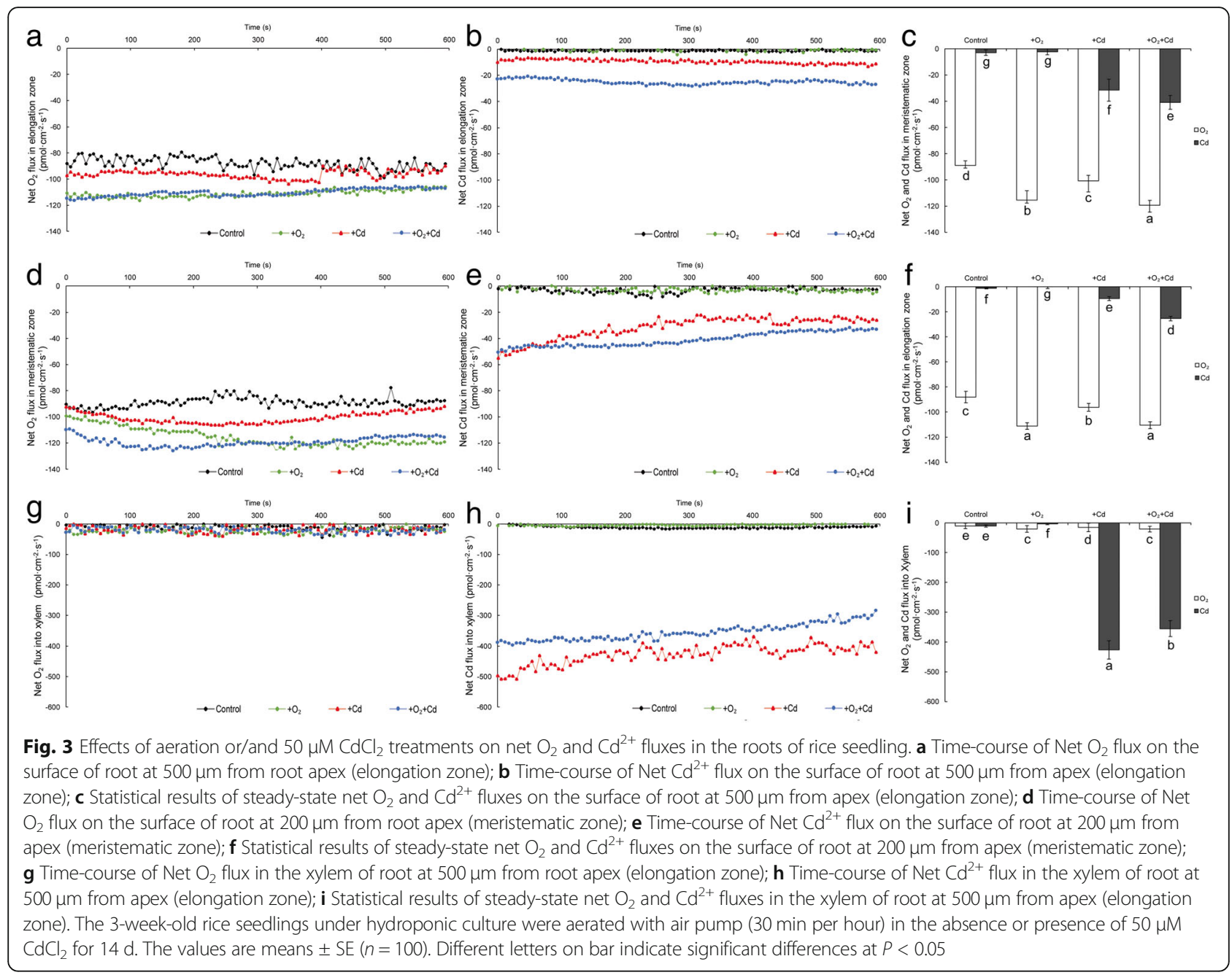

mature and senescence. In the presence of $\mathrm{Cd}$, aeration alleviated $\mathrm{Cd}$-caused inhibitions on and root length rather than dry weight (Fig. 1), indicating root elongation duration rather than root amount is regulated by aeration. In addition, aeration increased $\mathrm{Cd}$ content in roots (Fig. 5c) indicates aeration alleviates $\mathrm{Cd}$ toxicity by increasing $\mathrm{Cd}$ tolerance rather than by decreasing $\mathrm{Cd}$ absorption in rice roots. Figure 6 shows $\mathrm{Cd}$ in rice root was mainly restricted in the cell wall; it is a possible reason for the decreased $\mathrm{Cd}$ content in rice shoots in Fig. 5a.

$\mathrm{Cd}$ stress produces a series of toxic phenomenon in rice roots, and inhibition of root growth is one of the most significant symptoms (Xiong et al. 2009a). In this study, Cd significantly inhibited root length and dry weight (Fig. 1). Under disadvantage growth conditions, roots also undergo structural and functional modifications in order to adapt to biotic and abiotic stresses such as drought, nutrient deficiency, heavy metal and so on (de Dorlodot et al. 2007). All these heterogeneous events change during root development and some can result in the senescence or death of certain roots or the whole root system (Begara-Morales et al. 2013). Different from young, dividing and expanding meristematic zone in root tips, mature and senescent zone of rice root forms vascular tissues and disintegrated spongy cortex (aerenchyma). In this study, transverse sections showed that $\mathrm{Cd}$ treatment accelerated rice roots presenting mature and senescent symptoms such as promoted aerenchyma development and reduced parenchyma cells (Fig. 2), these mature and senescent symptoms can not only facilitate net $\mathrm{O}_{2}$ flux uptake but also decrease net $\mathrm{Cd}^{2+}$ flux uptake in rice roots (Fig. 3). All of these evidences indicate that $\mathrm{Cd}$ treatment can accelerate root mature and senescence of rice roots.

Oxygen is positive for the growth of rice, aerobic cultivation and other methods to increase the amount of rhizosphere oxygen can significantly promote the growth of rice (Zhu et al. 2015; Yang et al. 2017). In this study, aeration treatment promoted rice seedling growth, especially root growth, significantly (Fig. 1). Transverse sections showed that aeration increased cell expansion and reduced aerenchyma development (Fig. 2). Aeration not 

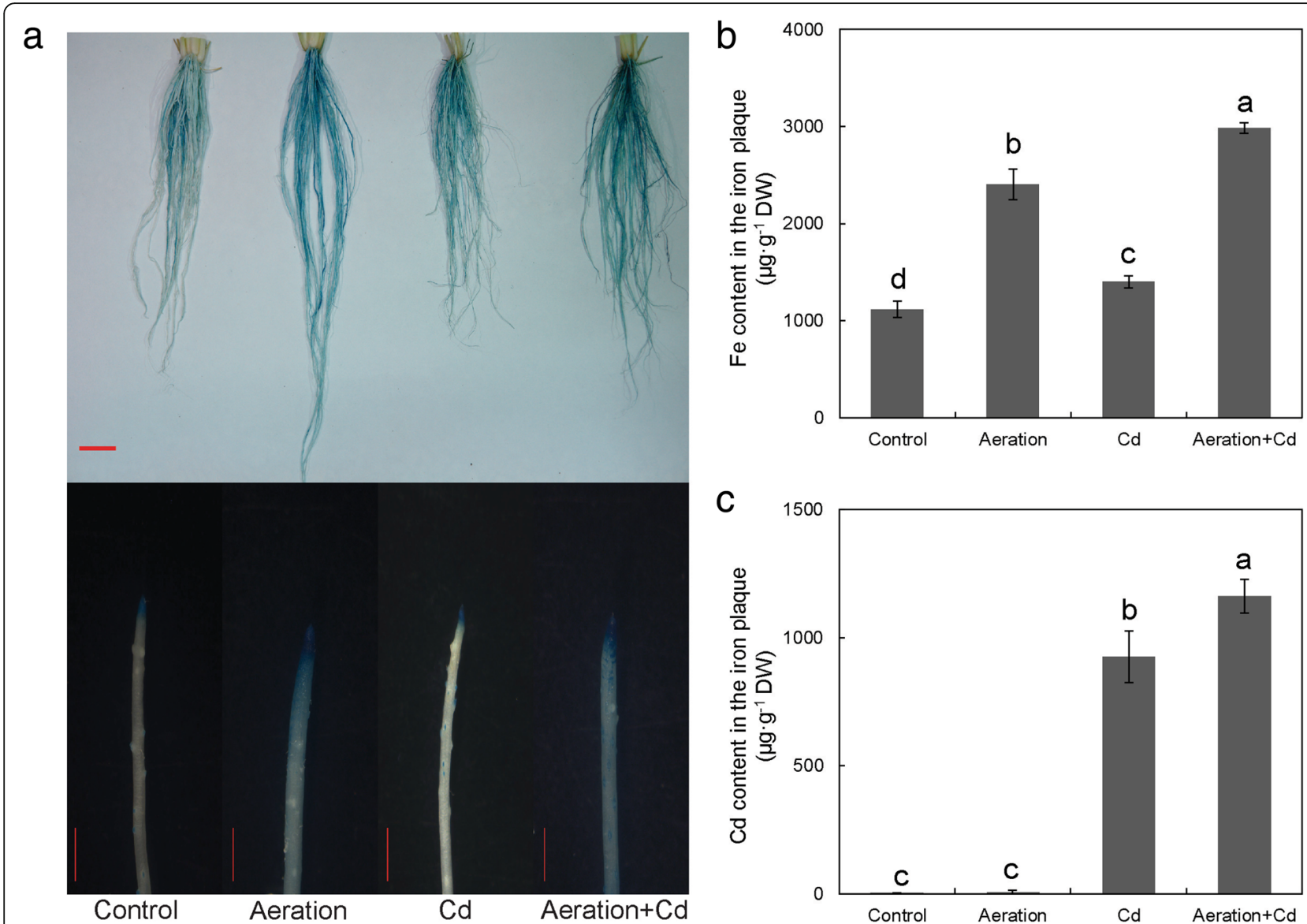

Fig. 4 Effects of aeration or/and $50 \mu \mathrm{M} \mathrm{CdCl}$ treatments on $\mathrm{Fe}$ and $\mathrm{Cd}$ content in the iron plaque of rice root. a Perls blue staining of iron plaque on the surface of rice roots, upper bar indicates $5 \mathrm{~cm}$ and lower bar indicate $1 \mathrm{~cm} ; \mathbf{b}$ Fe content in the iron plaque of rice roots; $\mathbf{c} C d$ content in the iron plaque of rice roots. The 3-week-old rice seedlings under hydroponic culture were aerated with air pump (30 min per hour) in the absence or presence of $50 \mu \mathrm{M} \mathrm{CdCl}_{2}$ for $14 \mathrm{~d}$. The values are means $\pm \mathrm{SE}(n=3)$. Different letters on bar indicate significant differences at $P<0.05$

only partly recovered Cd-inhibited root growth but also inhibited formation of disintegrated spongy cortex. As a wetland plant, rice forms continuous and spongy aerenchyma tissue facilitating gas transport from and to the aerial parts of the seedling. However, the development of gas-impermeable aerenchyma seems likely to impair the ability of the root to absorb nutrients (Kirk 2003). It is a possible strategy for rice reducing $\mathrm{Cd}$ toxicity, because $\mathrm{Cd}$-induced formation of aerenchyma seems likely to reduce $\mathrm{Cd}$ absorption in rice root. In addition, root aeration supplies sufficient oxygen for rice seedling growth, so it is not worth to impair nutrient absorption to develop gas-impermeable aerenchyma. Aerenchyma formation is through programmed cell death in the root cortex (Steffens et al. 2011), it is a broad consensus that aerenchyma formation in flooded roots is triggered by accumulation of ethylene, $\mathrm{Ca}^{2+}$ and reactive oxygen species (ROS) signaling (Drew et al. 2000; Evans 2004; Rajhi et al. 2011; Yamauchi et al. 2014).

\section{Aeration Enhances Cd Retention on Root Surface by Increasing Iron Plaque}

For a long time, the formation of iron plaque is due to the radial oxygen loss (ROL) and oxidants in the rhizosphere, where ferrous is subsequently oxidized to ferric iron with the precipitation of iron oxide or hydroxide on the root surface (Chen et al. 1980; Taylor et al. 1984). Here, we newly reported that root aeration, an exogenous $\mathrm{O}_{2}$ supply, in hydroponic experiment also significantly increased iron plaque formation on rice root surface (Fig. 4). Aeration also increased malondialdehyde (MDA) content in the roots under aeration, even if aeration decreased the MDA content of rice shoots (Additional file 1: Figure S1). MDA is a product of membrane lipid peroxidation in plant tissues and indirectly reflects oxidation stress. It's possible that aeration increase ROS and form iron plaques on the roots indirectly, but more direct evidences are still needed. More interesting, $\mathrm{Cd}$ treatment also increased iron plaque significantly in both presence and absence of aeration. All these evidences 

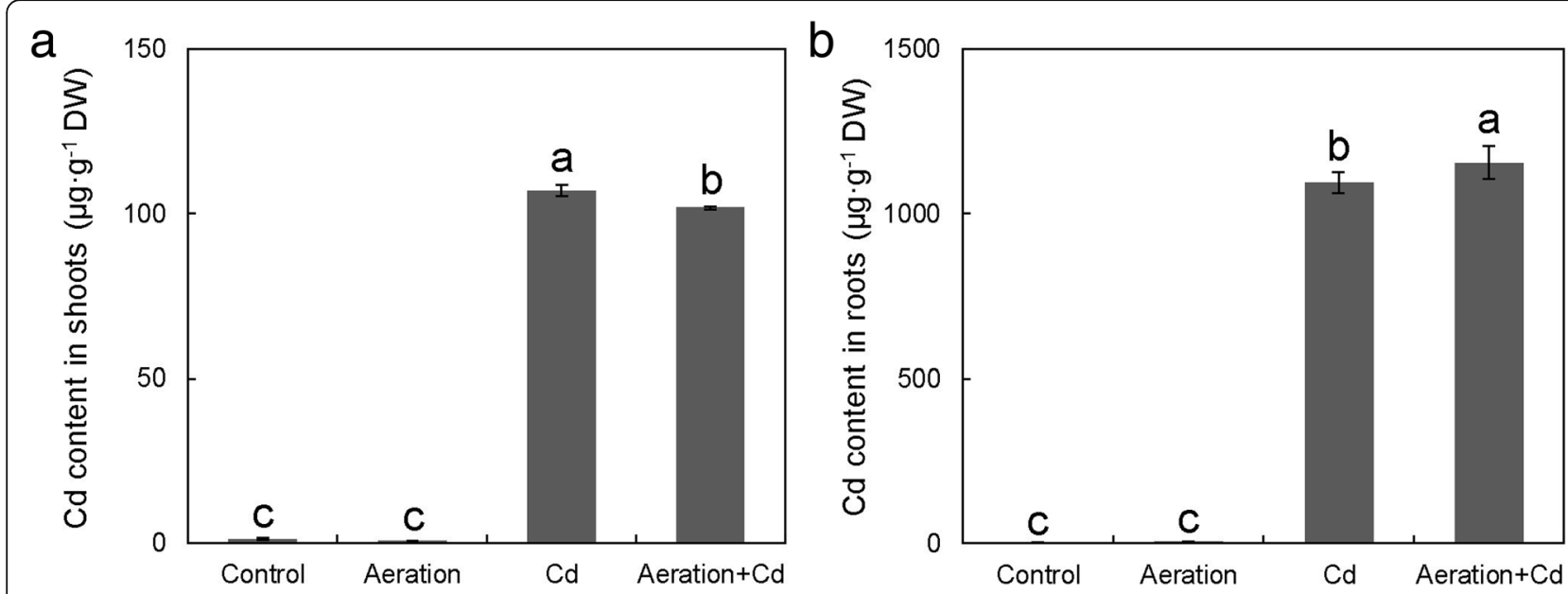

C

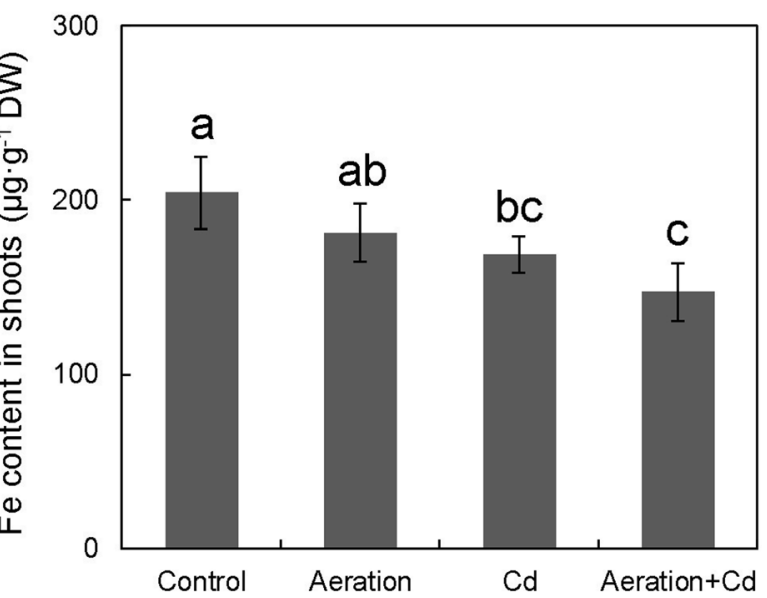

d

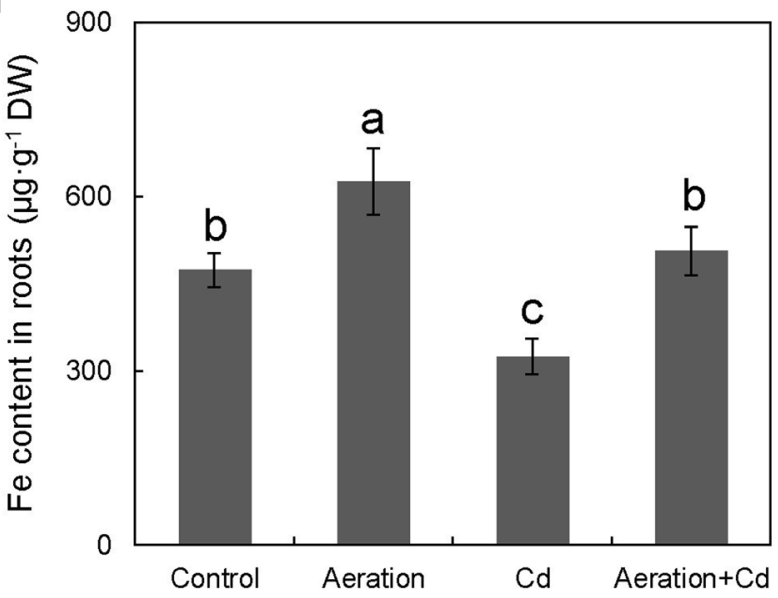

Fig. 5 Effects of aeration or/and $50 \mu \mathrm{M} \mathrm{CdCl}$ treatments on $\mathrm{Cd}$ and Fe content in shoots and roots of rice seedling. a Cd content in shoots; $\mathbf{b}$ $\mathrm{Cd}$ content in roots; c Fe content in shoots; $\mathbf{d}$ Fe content in roots. The 3-week-old rice seedlings under hydroponic culture were aerated with air pump (30 min per hour) in the absence or presence of $50 \mu \mathrm{M} \mathrm{CdCl}_{2}$ for $14 \mathrm{~d}$. The values are means $\pm \mathrm{SE}(n=3)$. Different letters on bar indicate significant differences at $P<0.05$

indicated that ROL is not the only reason for iron plaque formation on the surface of rice roots.

Iron plaque is considered can act as a filter for toxic metals, reacting and therefore immobilizing and preventing toxic metals uptake ( $\mathrm{Pi}$ et al. 2010). Previous studies have shown that iron plaque can immobilize heavy metals such as $\mathrm{Cd}$ by adsorption and coprecipitation (Du et al. 2013). In this research, we also found a relative high concentration (about $900 \mu \mathrm{g} / \mathrm{g} \mathrm{DW})$ of $\mathrm{Cd}$ in the iron plaque of rice roots (Fig. 4c). Furthermore, aeration significantly increased $\mathrm{Cd}$ retention in iron plaque (Fig. 4c). In addition, results of NMT analysis showed that aeration increased net $\mathrm{Cd}^{2+}$ flux on the surface of rice roots (Fig. 3b, e). All of these results showed that aeration enhances $\mathrm{Cd}$ retention on root surface by increasing plaque. These results are consistent with previous study, which got similar result with aeration treatments on iron plaque formation (Wu et al. 2012).
Compared with a relative high concentration (about $900 \mu \mathrm{g} / \mathrm{g} \mathrm{DW})$ in iron plaque on the surface of rice root, $\mathrm{Cd}$ concentration in roots is slightly higher (Fig. 5b). Aeration increased $\mathrm{Cd}$ content in rice roots, but it decreased $\mathrm{Cd}$ content in the shoots (Fig. 5a). Similarly, Yang et al. (2009) reported that moderate soil drying and severe soil drying increased $\mathrm{Cd}$ content in roots while they reduced it in the straw. Following uptake by roots, $\mathrm{Cd}$ is transported to shoots via xylem and phloem, where exist a large amount of vascular bundles (Yoneyama et al. 2015). NMT analysis showed that aeration decreased net $\mathrm{Cd}^{2+}$ flux in the xylem of rice roots (Fig. 3h). All of these evidences indicate that aeration increased $\mathrm{Cd}$ retention in iron plaque and inhibited $\mathrm{Cd}$ translocation from the roots to the shoots by reducing xylem loading.

Previous researches showed that moderate or internal soil drying increased $\mathrm{Cd}$ accumulation in rice roots (Yang et al. 2009). Cd presented as free $\mathrm{Cd}^{2+}$ in soil under aerobic condition was thought to be the reason 


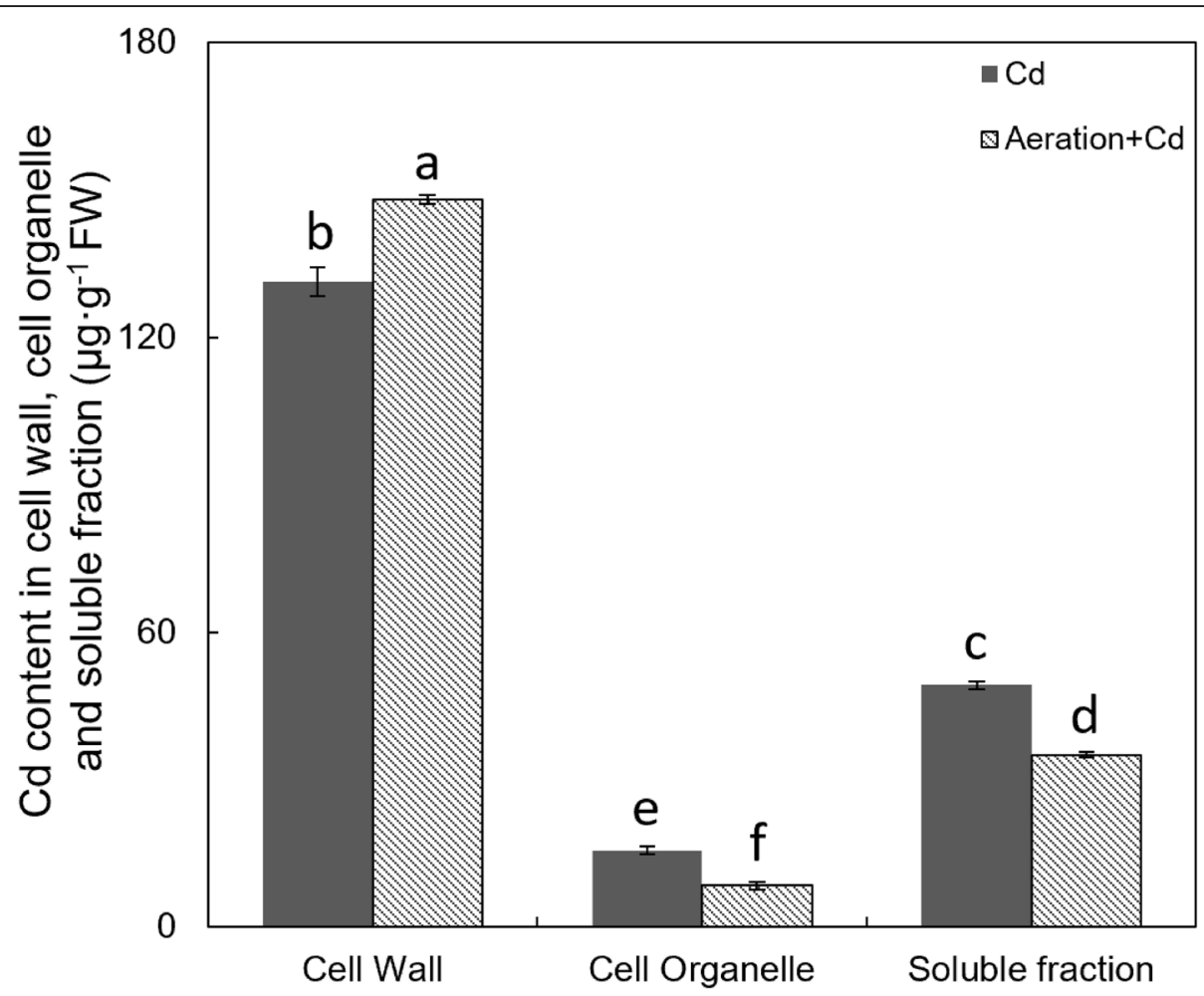

Fig. 6 Effects of aeration or/and $50 \mu \mathrm{M} \mathrm{CdCl}$ treatments on the location of $\mathrm{Cd}$ in rice root cells. Figure indicates $\mathrm{Cd}$ content in cell wall, cell organelle and soluble fraction. The 3-week-old rice seedlings under hydroponic culture were aerated with air pump (30 min per hour) in the absence or presence of $50 \mu \mathrm{M} \mathrm{CdCl}_{2}$ for $14 \mathrm{~d}$. The values are means $\pm \mathrm{SE}(n=3)$. Different letters on bar indicate significant differences at $P<0.05$

for increased Cd content in rice (Du Laing et al. 2009). Here, our hydroponic experiment results also showed that aeration increased $\mathrm{Cd}$ accumulation in rice roots (Fig. 5b). It seems that besides increasing free $\mathrm{Cd}^{2+}$ in soil, $\mathrm{O}_{2}$ also increases $\mathrm{Cd}$ accumulation in rice roots through other ways. So, further studies are needed to discover the roles of $\mathrm{O}_{2}$ in regulating $\mathrm{Cd}$ accumulation in rice roots.

\section{Aeration Enhances Cd Retention in Root Cell Wall by Regulating Pectin Synthesis}

Results of root cell fraction analysis showed that $\mathrm{Cd}$ in rice roots mainly accumulated in the cell wall and aeration increased $\mathrm{Cd}$ accumulation in the cell wall rather than cell organelle or soluble fraction (Fig. 6). There is a close positive correlation between pectin content and $\mathrm{Cd}$ accumulation in cell walls (Xiong et al. 2009b). Further researches by Paynel et al. (2009) have indicated that Cd induces an increase in PME activity and causes a decrease of pectin methylesterification degree, which determines negative charges and has a close negative correlation with heavy metal adsorption in the cell walls of plant roots (Eticha et al. 2005; Yang et al. 2008). As previous report (Xiong et al. 2009b), Cd treatment increased pectin, $\mathrm{HC} 1$ and $\mathrm{HC} 2$ content in rice roots
(Fig. 7). Moreover, aeration also increased pectin content in rice in the absence of $\mathrm{Cd}$, enzyme activity analysis showed that aeration increased PME activity and decreased pectin methylesterification degree in the cell wall of rice roots (Fig. 8). All of these results suggested aeration enhances $\mathrm{Cd}$ retention in root cell wall by regulating pectin synthesis and methylesterification. In addition, our previous report has showed that exogenous $\mathrm{H}_{2} \mathrm{O}_{2}$ not only increased pectin content but also increased PME activity and decreased pectin methylesterification degree in rice roots (Xiong et al. 2015). So that, further studies are need to investigate the effect of aeration on $\mathrm{H}_{2} \mathrm{O}_{2}$ accumulation in rice roots. In addition, aeration may increase pectin synthesis by delaying root mature and senescence, because pectin is mainly synthesized in young, dividing and expanding cell in elongation and meristematic zones of roots.

\section{Cd Stress and Aeration Increases Fe Accumulation in Iron Plaque while Decreases Fe Accumulation in Roots and Shoots of Rice Seedlings}

It's well-known that there is competitive interaction between $\mathrm{Fe}$ and $\mathrm{Cd}$ due to similar transport route within plants (Sharma et al. 2004). In resistance to Cd, plants tend to take up more Fe and act as a defence mechanism 

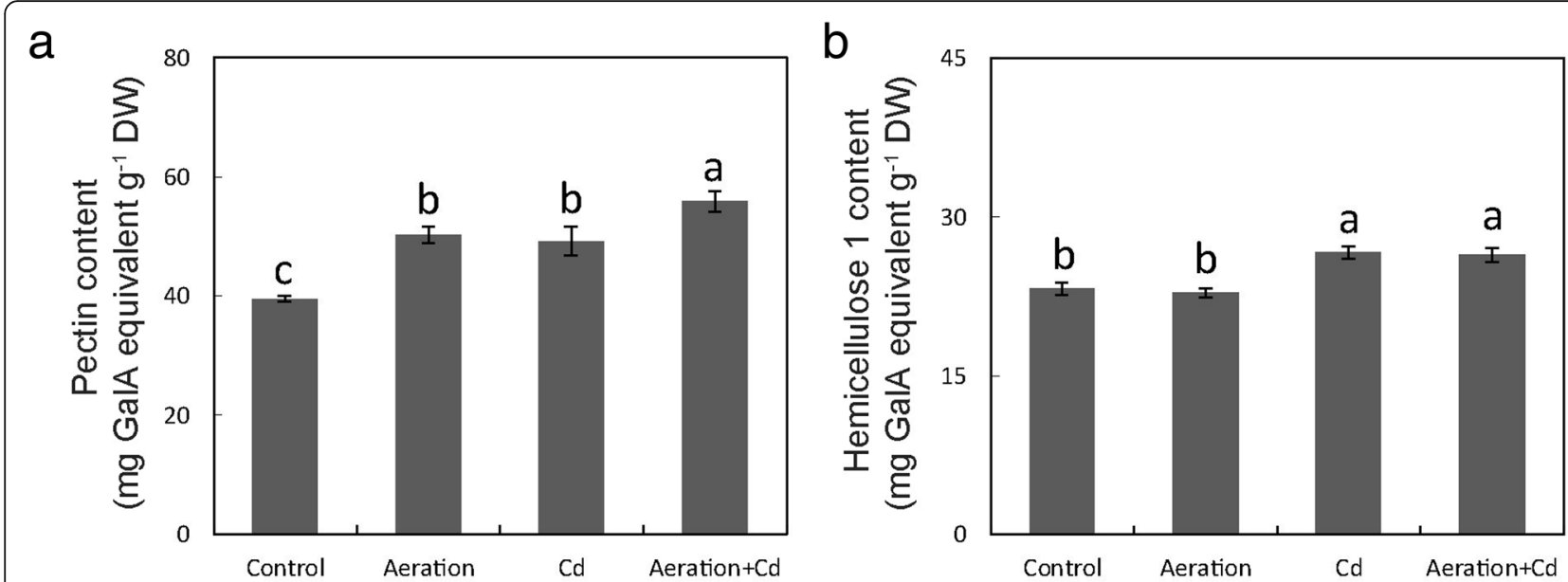

C
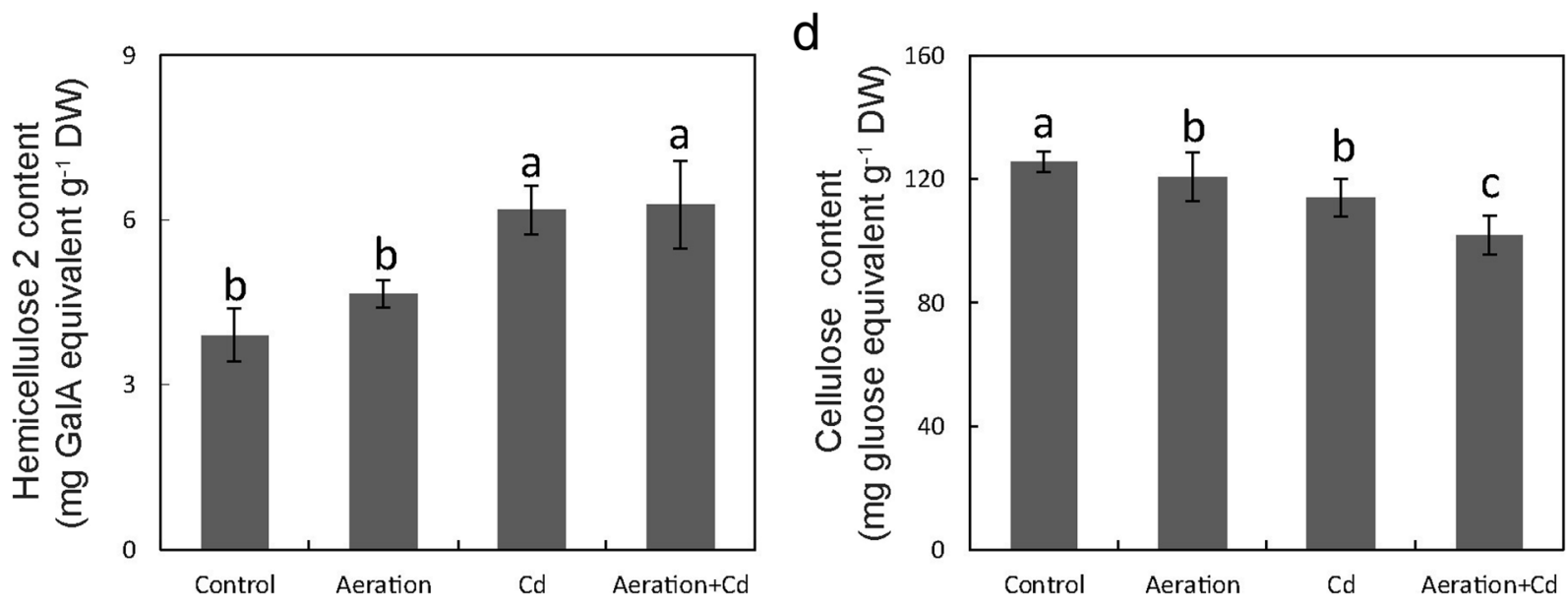

Fig. 7 Effects of aeration or/and $50 \mu \mathrm{M} \mathrm{CdCl}_{2}$ treatments on cell wall components in rice root. a Pectin content in the cell wall of root; $\mathbf{b}$ Hemicellulose 1 ( $\mathrm{HC} 1$ ) content in the cell wall of root; $\mathbf{c}$ Hemicellulose 2 ( $\mathrm{HC} 2$ ) content in the cell wall of root; d Cellulose content in the cell wall of root. The 3-week-old rice seedlings under hydroponic culture were aerated with air pump (30 min per hour) in the absence or presence of 50 $\mu \mathrm{M} \mathrm{CdCl} 2$ for $14 \mathrm{~d}$. The values are means $\pm \mathrm{SE}(n=3)$. Different letters on bar indicate significant differences at $P<0.05$
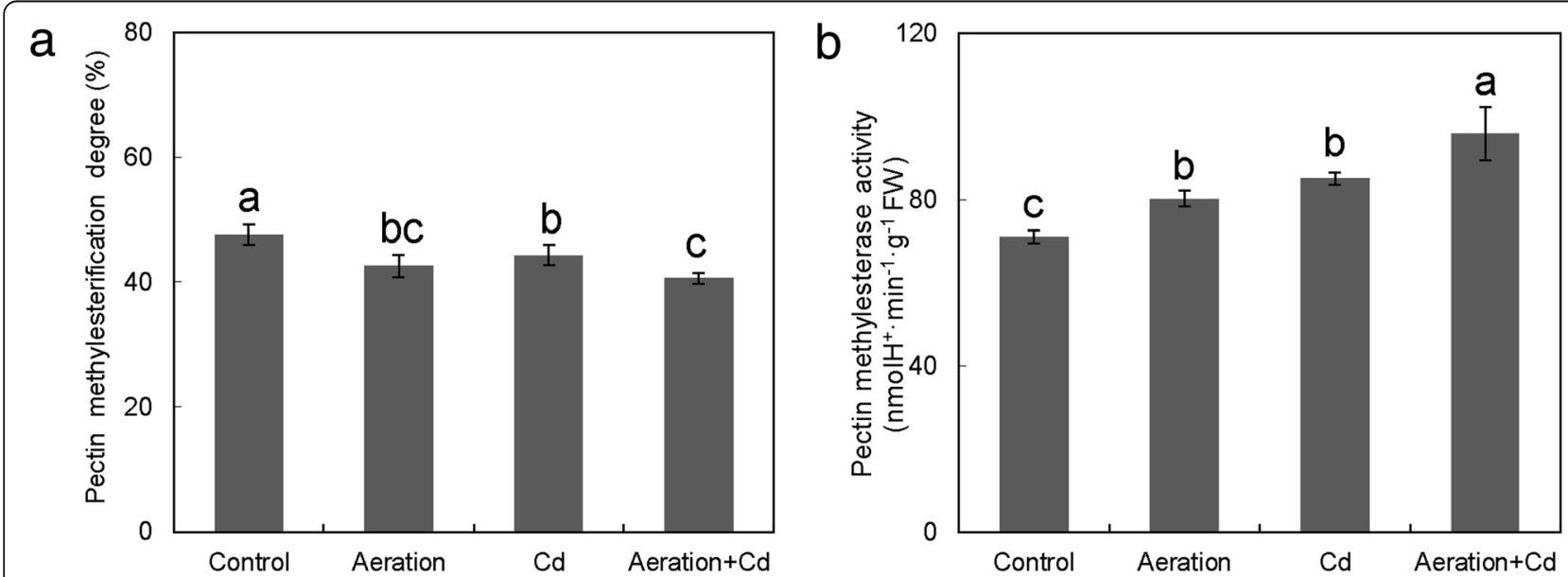

Fig. 8 Effects of aeration or/and $50 \mu \mathrm{MCdCl}_{2}$ treatments on pectin synthesis in the cell wall of rice root. a Pectin methylesterification degree (PMD) in rice root; $\mathbf{b}$ Pectin methylesterase (PME) activity in rice root. The 3-week-old rice seedlings under hydroponic culture were aerated with air pump (30 min per hour) in the absence or presence of $50 \mu \mathrm{M} \mathrm{CdCl}$ for $14 \mathrm{~d}$. The values are means $\pm \mathrm{SE}(n=3)$. Different letters on bar indicate significant differences at $P<0.05$ 
to prevent $\mathrm{Cd}$ from entering into root (Astolfi et al. 2014; Gong et al. 2015). Several studies showed that exogenous $\mathrm{Fe}$ supply resulted in decreased $\mathrm{Cd}$ uptake while increased Fe uptake in rice (Liu et al. 2008; Shao et al. 2008; Sebastian and Prasad 2015). According to the competitive interaction between $\mathrm{Cd}$ and $\mathrm{Fe}$, $\mathrm{Cd}$ stress should decrease rather than increase Fe uptake in rice roots, but previous reports (Yoshihara et al. 2006; Meda et al. 2007; Gao et al. 2011), including our previous report (Yang et al. 2016), showed that $\mathrm{Cd}$ treatment significantly increased $\mathrm{Fe}$ content in root. Why did this "contradiction" happen?

Here, our results discovered the explanation for this "contradiction". If fact, $\mathrm{Cd}$ treatment mainly increased $\mathrm{Fe}$ content in iron plaque on the surface of rice roots (Fig. 4b), but it indeed decreased $\mathrm{Fe}$ contents in both shoots and roots (after the DCB extraction of iron plaque) of rice seedlings (Fig. 5). This result indicates that it is necessary to consider and wash down iron plaque before determining real metal concentration in rice roots.

As to Fe content, aeration increased Fe content in roots but had no obvious effect on $\mathrm{Fe}$ content in shoots in rice seedlings without $\mathrm{Cd}$ treatment (Fig. $5 \mathrm{c}$, d). These results indicate $\mathrm{Fe}$ was restricted in roots too. After absorbed by the roots, Fe can be transported to the vascular bundle by both apoplast and symplast system, and then transported to the shoots through the xylem and phloem (Yoneyama et al. 2015). In addition to the symplast pathway, the apoplast pathway is also an important transport route. And the cell wall is an important component of the apoplast. Due to the increase of pectin content in the cell wall caused by aeration (Figs. 7, 8), the binding ability of cell walls to $\mathrm{Fe}$ also increased. However, as shown in Additional file 1: Figure S2), aeration had different effect on $\mathrm{Cu}, \mathrm{Zn}$ and $\mathrm{Mn}$ content in rice roots and shoots, indicating pectin binding is not the unique strategy for restricting $\mathrm{Fe}$ and $\mathrm{Cd}$ in the cell wall. In addition, the effects of aeration on Fe transporter expression remains unclear, more researches are still required to discover the detailed mechanism.

\section{Conclusions}

Aeration, a method different from moderate or internal soil drying in increasing rhizosphere oxygen amount, alleviates $\mathrm{Cd}$ toxicity to rice seedlings by increasing net $\mathrm{O}_{2}$ and $\mathrm{Cd}^{2+}$ influxes on the surface of rice root. Then the increased net $\mathrm{O}_{2}$ influx delays $\mathrm{Cd}$-accelerated mature and senescence of roots, increases iron plaque formation and $\mathrm{Cd}$ retention, promotes pectin synthesis and demesterification in the cell wall and decreases $\mathrm{Cd}$ translocation from roots to shoots.

\section{Additional file}

Additional file 1: Figure S1. Effects of aeration or/and $50 \mu \mathrm{M} \mathrm{CdCl}_{2}$ treatments on malondialdehyde (MDA) content in shoots and roots of rice seedling. (a) MDA content in shoots; (b) MDA content in roots. The 3 -week-old rice seedlings under hydroponic culture were aerated with air pump (30 min per hour) in the absence or presence of $50 \mu \mathrm{M} \mathrm{CdCl}_{2}$ for $14 \mathrm{~d}$. The values are means \pm SE $(n=3)$. Different letters on bar indicate significant differences at $P<0.05$. Figure S2. Effects of aeration or/and $50 \mu \mathrm{M} \mathrm{CdCl}$ 2 treatments on $\mathrm{Cu}, \mathrm{Zn}$ and $\mathrm{Mn}$ content in shoots and roots of rice seedling. (a) Cu content in shoots; (b) Cu content in roots; (c) Zn content in shoots; (d) Zn content in roots; (e) Mn content in shoots; ( $f$ ) $\mathrm{Mn}$ content in roots; The 3-week-old rice seedlings under hydroponic culture were aerated with air pump (30 min per hour) in the absence or presence of $50 \mu \mathrm{M} \mathrm{CdCl}$ for $14 \mathrm{~d}$. The values are means \pm SE $(n=3)$. Different letters on bar indicate significant differences at $P<0.05$. (DOCX $2357 \mathrm{~kb}$ )

\section{Abbreviations}

DCB: Dithionite-citrate-bicarbonate method; MD: Re-watered when soil water potential decreased to -20 kPa; NMT: On-invasive Micro-test Technology; PC: Phytochelatins; PMD: Pectin methylesterification degree; PME: Pectin methylesterase; SD: Re-watered when soil water potential decreased to -40 $\mathrm{kPa}$

\section{Acknowledgements}

This research was supported by Zhejiang Provincial Natural Science Foundation of China under Grant No. LY18C130011 and LY15C130007, Science Foundation of Zhejiang Sci-Tech University, Foundation of Zhejiang Provincial Top Key Discipline of Biology and Foundation of Zhejiang Provincial Key Discipline of Botany.

\section{Funding}

This research was supported by Zhejiang Provincial Natural Science Foundation of China under Grant No. LY18C130011 and LY15C130007, Science Foundation of Zhejiang Sci-Tech University, Foundation of Zhejiang Provincial Top Key Discipline of Biology and Foundation of Zhejiang Provincial Key Discipline of Botany.

Availability of Data and Materials

All data generated or analyzed during this study are included in this published article.

\section{Authors' Contributions}

$J X$ and $L T$ designed the research. $H L, X Z, L G$ and $Y Y$ performed the experiments. JX and $\mathrm{HL}$ analyzed the data. $\mathrm{HL}$ and JX wrote the paper with contributions from all the authors. All authors read and approved the final manuscript.

\section{Ethics Approval and Consent to Participate}

There has no ethics problems involved in this article.

\section{Consent for Publication}

These co-authors involved in the paper all consent to publish this article on Rice.

\section{Competing Interests}

The authors declare that they have no competing interests.

\section{Publisher's Note}

Springer Nature remains neutral with regard to jurisdictional claims in published maps and institutional affiliations.

\section{Author details}

'School of Life Sciences and Medicine, Zhejiang Sci-Tech University, Hangzhou 310018, People's Republic of China. 'State Key Laboratory of Rice Biology, China National Rice Research Institute, Hangzhou 310006, People's Republic of China. 


\section{Received: 6 November 2018 Accepted: 15 April 2019}

\section{Published online: 02 May 2019}

\section{References}

Anthon GE, Barrett DM (2004) Comparison of three colorimetric reagents in the determination of methanol with alcohol oxidase. Application to the assay of pectin methylesterase. J Agric Food Chem 52:3749-3753

Anthon GE, Barrett DM (2008) Combined enzymatic and colorimetric method for determining the uronic acid and methylester content of pectin: application to tomato products. Food Chem 110:239-247

Astolfi S, Ortolani MR, Catarcione G, Paolacci AR, Cesco S, Pinton R, Ciaffi M (2014) Cadmium exposure affects iron acquisition in barley (Hordeum vulgare) seedlings. Physiol Plant 152:646-659

Bailey-Serres J, Voesenek LA (2008) Flooding stress: acclimations and genetic diversity. Annu Rev Plant Biol 59:313-319

Begara-Morales JC, Chaki M, Sánchez-Calvo B, Mata-Pérez C, Leterrier M, Palma JM, Barroso JB, Corpas FJ (2013) Protein tyrosine nitration in pea roots during development and senescence. J Exp Bot 64:1121-1134

Blumenkrantz N, Asboe-Hansen G (1973) New method for quantitative determination of uronic acids. Anal Biochem 54:484-489

Carrier P, Baryla A, Havaux M (2003) Cadmium distribution and microlocalization in oilseed rape (Brassica napus) after long-term growth on cadmiumcontaminated soil. Planta 216:939-950

Cattani I, Romani M, Boccelli R (2008) Effect of cultivation practices on cadmium concentration in rice grain. Agron Sustain Dev 28:265-271

Chabbi A (1999) Juncus bulbosus as a pioneer species in acidic lignite mining lakes: interactions, mechanism and survival strategies. New Phytol 144:133-142

Chen CC, Dixon JB, Turner FT (1980) Iron coatings on rice roots: morphology and models of development. Soil Sci Soc Am J 44:1113-1119

Chen RF, Shen RF, Gu P, Dong XY, Du CW, Ma JF (2006) Response of rice (Oryza sativa) with root surface iron plaque under aluminium stress. Ann Bot 98: 389-395

Choppala G, Saifullah Bolan N, Bibi S, Iqbal M, Rengel Z, Kunhikrishnan A, Ashwath N, Yong SO (2014) Cellular mechanisms in higher plants governing tolerance to cadmium toxicity. Crit Rev Plant Sci 33:374-391

CODEX (2006) Report of the 38th session of the Codex Committee on Food Additives and Contaminants. Codex Alimentarius Commission. ALINORM 06/ 29/12, pp 1-12

Correa-Aragunde N, Lombardo C, Lamattina L (2008) Nitric oxide: an active nitrogen molecule that modulates cellulose synthesis in tomato roots. New Phytol 179:386-396

Dalcorso G, Farinati S, Furini A (2010) Regulatory networks of cadmium stress in plants. Plant Signal Behav 5:663-667

Daum D, Bogdan K, Schenk MK, Merkel D (2001) Influence of the field water management on accumulation of arsenic and cadmium in paddy rice. Dev Plant Soil Sci 92:290-291

de Dorlodot S, Forster B, Pagès L, Price A, Tuberosa R, Draye X (2007) Root system architecture: opportunities and constraints for genetic improvement of crops. Trends Plant Sci 12:474-481

Deng $\mathrm{H}$, Ye Z, Wong M (2009) Lead, zinc and iron $\left(\mathrm{Fe}^{2+}\right)$ tolerances in wetland plants and relation to root anatomy and spatial pattern of ROL. Environ Exp Bot 65:353-362

Drew MC, He CJ, Morgan PW (2000) Programmed cell death and aerenchyma formation in roots. Trends Plant Sci 5:123-127

Du J, Yan C, Li Z (2013) Formation of iron plaque on mangrove Kandalar. Obovata (S.L.) root surfaces and its role in cadmium uptake and translocation. Mar Pollut Bull 74:105-109

Du Laing G, Rinklebe J, Vandecasteele B, Meers E, Tack FM (2009) Trace metal behaviour in estuarine and riverine floodplain soils and sediments: a review. Sci Total Environ 407:3972-3985

Eticha D, Staß A, Horst WJ (2005) Localization of aluminium in the maize root apex: can morin detect cell wall-bound aluminium? J Exp Bot 56:1351-1357

Evans DE (2004) Aerenchyma formation. New Phytol 161:35-49

Gao C, Wang Y, Xiao DS, Qiu CP, Han DG, Zhang XZ, Wu T, Han ZH (2011) Comparison of cadmium-induced iron-deficiency responses and genuine iron-deficiency responses in Malus xiaojinensis. Plant Sci 181:269-274

Gong X, Yin L, Chen J, Guo C (2015) Overexpression of the iron transporter NtPIC, in tobacco mediates tolerance to cadmium. Plant Cell Rep 34:1963-1973

Horiguchi H, Teranishi H, Niiya K, Aoshima K, Katoh T, Sakuragawa N, Kasuya M (1994) Hypoproduction of erythropoietin contributes to anemia in chronic cadmium intoxication: clinical study on Itai-itai disease in Japan. Arch Toxicol 168:632-636
Hu P, Huang J, Ouyang Y, Wu L, Song J, Wang S, Li Z, Han C, Zhou L, Huang Y, Luo Y, Christie P (2013a) Water management affects arsenic and cadmium accumulation in different rice cultivars. Environ Geochem Health 35:767-778

Hu P, Li Z, Yuan C, Ouyang Y, Zhou L, Huang J, Huang Y, Luo Y, Christie P, Wu L (2013b) Effect of water management on cadmium and arsenic accumulation by rice (Oryza sativa L.) with different metal accumulation capacities. I Soils Sediments 13:916-924

Ishikawa S, Ae N, Murakami M, Wagatsuma T (2006) Is Brassica juncea a suitable plant for phytoremediation of cadmium in soils with moderately low cadmium contamination? -possibility of using other plant species for $\mathrm{Cd}$ phytoextraction. Soil Sci Plant Nutr 52:32-42

Ishikawa S, Suzui N, Ito-Tanabata S, Ishii S, Igura M, Abe T, Kuramata M, Kawachi $\mathrm{N}$, Fujimaki S (2011) Real-time imaging and analysis of differences in cadmium dynamics in rice cultivars (Oryza sativa) using positron-emitting ${ }^{107} \mathrm{Cd}$ tracer. BMC Plant Biol 11:172

Kirk GJD (2003) Rice root properties for internal aeration and efficient nutrient acquisition in submerged soil. New Phytol 159:185-194

Kohn R (1987) Binding of divalent cations to oligomeric fragments of pectin. Carbohydr Res 160:343-353

Liners F, Letesson JJ, Didembourg C, Van C (1989) Monoclonal antibodies against pectin: recognition of a conformation induced by calcium. Plant Physiol 91: $1419-1424$

Liu H, Zhang J, Christie P, Zhang F (2007) Influence of external zinc and phosphorus supply on $\mathrm{Cd}$ uptake by rice (Oryza sativa L.) seedlings with root surface iron plaque. Plant Soil 300:105-115

Liu H, Zhang J, Christie P, Zhang F (2008) Influence of iron plague on uptake and accumulation of $\mathrm{Cd}$ by rice (Oryza sativa L.) seedlings grown in soil. Sci Total Environ 394:361-368

Lux A, Martinka M, Vaculík M, White PJ (2011) Root responses to cadmium in the rhizosphere: a review. J Exp Bot 62:21-37

Makino T, Takano H, Kamiya T, Itou T, Sekiya N, Inahara M, Sakurai Y (2008) Restoration of cadmium-contaminated paddy soils by washing with ferric chloride: $\mathrm{Cd}$ extraction mechanism and bench-scale verification. Chemosphere 70:1035-1043

Meda AR, Scheuermann EB, Prechsl UE, Erenoglu B, Schaaf G, Hayen H, Wirén v (2007) Iron acquisition by phytosiderophores contributes to cadmium tolerance. Plant Physiol 143:1761-1773

Micheli F (2001) Pectin methylesterases: cell wall enzymes with important roles in plant physiology. Trends Plant Sci 6:414-419

Miyadate H, Adachi S, Hiraizumi A, Tezuka K, Nakazawa N, Kawamoto T, Katou K, Kodama I, Sakurai K, Takahashi H, Satoh-Nagasawa N, Watanabe A, Fujimura T, Akagi H (2011) OsHMA3, a P1B-type of ATPase affects root-to-shoot cadmium translocation in rice by mediating efflux into vacuoles. New Phytol 189:190-199

Nakanishi H, Ogawa I, Ishimaru Y, Mori S, Nishizawa NK (2006) Iron deficiency enhances cadmium uptake and translocation mediated by the $\mathrm{Fe}^{2+}$ transporters OsIRT1 and OsIRT2 in rice. Soil Sci Plant Nutr 52:464-469

Pang J, Zhou M, Mendham N, Shabala S (2004) Growth and physiological responses of six barley genotypes to waterlogging and subsequent recovery. Aust J Agr Res 55:895-906

Paynel F, Schaumann A, Arkoun M, Douchiche O, Morvan C (2009) Temporal regulation of cell-wall pectin methylesterase and peroxidase isoforms in cadmium-treated flax hypocotyl. Ann Bot 104:1363-1372

Pi N, Tam NFY, Wong MH (2010) Effects of wastewater discharge on formation of Fe plaque on root surface and radial oxygen loss of mangrove roots. Environ Pollut 158:381-387

Poschenrieder C, Gunsé B, Barceló J (1989) Influence of cadmium on water relations, stomatal resistance, and abscisic acid content in expanding bean leaves. Plant Physiol 90:1365-1371

Rajhi I, Yamauchi T, Takahashi H, Nishiuchi S, Shiono K, Watanabe R, Mliki A, Nagamura Y, Tsutsumi N, Nishizawa NK, Nakazono M (2011) Identification of genes expressed in maize root cortical cells during lysigenous aerenchyma formation using laser microdissection and microarray analyses. New Phytol 190:351-368

Ren C, Kermode AR (2000) An increase in pectin methylesterase activity accompanies dormancy breakage and germination of yellow cedar seeds. Plant Physiol 124:231-242

Richard L, Qin LX, Gadal P, Goldberg R (1994) Molecular characterization of a putative pectin methylesterase CDNA and its expression in Arabidopsis thaliana L. FEBS Lett 355:135-139

Sasaki A, Yamaji N, Yokosho K, Ma J (2012) Nramp5 is a major transporter responsible for manganese and cadmium uptake in rice. Plant Cell 24:2155-2167 
Schmohl N, Horst W (2000) Cell wall pectin content modulates aluminium sensitivity of Zea mays (L.) cells grown in suspension culture. Plant Cell Environ 23:735-742

Sebastian A, Prasad MNV (2015) Iron-and manganese-assisted cadmium tolerance in Oryza sativa L.: lowering of rhizotoxicity next to functional photosynthesis. Planta 241:1519-1528

Shao G, Chen M, Wang D, Xu C, Mou R, Cao Z, Zhang X (2008) Using iron fertilizer to control $\mathrm{Cd}$ accumulation in rice plants: a new promising technology. Sci China C Life Sci 51:245-253

Sharif MK, Butt MS, Anjum FM, Khan SH (2014) Rice bran: a novel functional ingredient. Crit Rev Food Sci Nutr 54:807-816

Sharma SS, Kaul S, Metwally A, Goyal KC, Finkemeier I, Dietz KJ (2004) Cadmium toxicity to barley (Hordeum vulgare) as affected by varying Fe nutritional status. Plant Sci 166:1287-1295

Smethurst C, Garnett T, Shabala S (2005) Nutritional and chlorophyll fluorescence responses of Lucerne (Medicago sativa) to waterlogging and subsequent recovery. Plant Soil 270:31-45

Smolders AJP, Roelofs JGM (1996) The roles of internal iron hydroxide precipitation, Sulphide toxicity and oxidizing ability in the survival of Stratiotes aloides roots at different iron concentrations in sediment pore water. New Phytol 133:253-260

Steffens B, Geske T, Sauter M (2011) Aerenchyma formation in the rice stem and its promotion by $\mathrm{H}_{2} \mathrm{O}_{2}$. New Phytol 190:369-378

Takahashi R, Ishimaru Y, Senoura T, Shimo H, Ishikawa S, Arao T, Nakanishi H, Nishizawa NK (2011) The OsNRAMP1 iron transporter is involved in Cd accumulation in rice. J Exp Bot 62:4843-4850

Taylor G, Crowder A (1983) Use of the DCB technique for extraction of hydrous iron-oxides from roots of wetland plants. Am J Bot 70:1254-1257

Taylor G, Crowder A, Rodden R (1984) Formation and morphology of an iron plaque on the roots of Typha latifolia L. grown in solution culture. Am J Bot 71:666-675

Tsukahara T, Ezaki T, Moriguchi J, Furuki K, Shimbo S, Matsuda-Inoguchi N, Ikeda M (2003) Rice as the most influential source of cadmium intake among general Japanese population. Sci Total Environ 305:41-51

Ueno D, Koyama E, Yamaji N, Ma J (2011) Physiological, genetic, and molecular characterization of a high-Cd-accumulating rice cultivar, Jarjan. J Exp Bot 62: 2265-2272

Ueno D, Yamaji N, Kono I, Huang CF, Ando T, Yano M, Ma JF (2010) Gene limiting cadmium accumulation in rice. Proc Natl Acad Sci U S A 107:16500-16505

Uraguchi S, Watanabe I, Yoshitomi A, Kiyono M, Kuno K (2006) Characteristics of cadmium accumulation and tolerance in novel Cd-accumulating crops, Avena strigosa and Crotalaria juncea. J Exp Bot 57:2955-2965

Wu C, Ye Z, Li H, Wu S, Deng D, Zhu Y, Wong M (2012) Do radial oxygen loss and external aeration affect iron plaque formation and arsenic accumulation and speciation in rice? J Exp Bot 63:2961-2970

Xiong J, An L, Lu H, Zhu C (2009b) Exogenous nitric oxide enhances cadmium tolerance of rice by increasing pectin and hemicellulose contents in root cell wall. Planta 230:755-765

Xiong J, Lu H, Lu K, Duan Y, An L, Zhu C (2009a) Cadmium decreases crown root number by decreasing endogenous nitric oxide, which is indispensable for crown root primordia initiation in rice seedlings. Planta 230:599-610

Xiong J, Yang Y, Fu G, Tao $L$ (2015) Novel roles of hydrogen peroxide $\left(\mathrm{H}_{2} \mathrm{O}_{2}\right)$ in regulating pectin synthesis and demethylesterification in the cell wall of rice (Oryza sativa) root tips. New Phytol 206:118-126

Yadav R, Arora P, Kumar S, Chaudhury A (2010) Perspectives for genetic engineering of poplars for enhanced phytoremediation abilities. Ecotoxicology 19:1574-1588

Yamauchi T, Watanabe K, Fukazawa A, Mori H, Abe F, Kawaguchi K, Oyanagi A, Nakazono M (2014) Ethylene and reactive oxygen species are involved in root aerenchyma formation and adaptation of wheat seedlings to oxygendeficient conditions. J Exp Bot 65:261-273

Yang J, Huang D, Duan H, Tan G, Zhang J (2009) Alternate wetting and moderate soil drying increases grain yield and reduces cadmium accumulation in rice grains. J Sci Food Agric 89:1728-1736

Yang J, Li Y, Zhang Y, Zhang S, Wu Y, Wu P, Zheng S (2008) Cell wall polysaccharides are specifically involved in the exclusion of aluminum from the rice root apex. Plant Physiol 146:602-611

Yang J, Zhou Q, Zhang J (2017) Moderate wetting and drying increases rice yield and reduces water use, grain arsenic level, and methane emission. Crop J 5:151-158

Yang Y, Chen R, Fu G, Xiong J, Tao L (2016) Phosphate deprivation decreases cadmium (Cd) uptake but enhances sensitivity to $\mathrm{Cd}$ by increasing iron (Fe) uptake and inhibiting phytochelatins synthesis in rice (Oryza sativa). Acta Physiol Plant 38:28
Yokosho K, Yamaji N, Ueno D, Mitani N, Ma J (2009) OsFRDL1 is a citrate transporter required for efficient translocation of iron in rice. Plant Physio 149:297-305

Yoneyama T, Ishikawa S, Shu F (2015) Route and regulation of zinc, cadmium, and iron transport in rice plants (Oryza Sativa L.) during vegetative growth and grain filling: metal transporters, metal speciation, grain $\mathrm{Cd}$ reduction and Zn and Fe biofortification. Int J Mol Sci 16:19111-19129

Yoshida S, Forno DA, Cock JH, Gomez KA (1976) Laboratory manual for physiological studies of rice, 3rd edn. The International Rice Research Institute, Manila

Yoshihara T, Hodoshima H, Miyano Y, Shoji K, Shimada H, Goto F (2006) Cadmium inducible Fe deficiency responses observed from macro and molecular views in tobacco plants. Plant Cell Rep 25:365-373

Zhong H, Läuchli A (1993) Changes of cell wall composition and polymer size in primary roots of cotton seedlings under high salinity. J Exp Bot 44:773-778

Zhu J, Liang J, Xu Z, Fan X, Zhou Q, Shen Q, Xu G (2015) Root aeration improves growth and nitrogen accumulation in rice seedlings under low nitrogen. AoB Plants 7:plv131

\section{Submit your manuscript to a SpringerOpen ${ }^{\circ}$ journal and benefit from:}

- Convenient online submission

- Rigorous peer review

- Open access: articles freely available online

High visibility within the field

- Retaining the copyright to your article

Submit your next manuscript at $>$ springeropen.com 